Please send trade news information and illustrations to Arveen Bajaj at the BDJ, 64 Wimpole Street, London W1G 8YS.

Trade news is supplied as a service to the reader and does not imply endorsement by the BDJ. Normal and prudent research should be exercised before purchase of use of any product mentioned.

\section{TRADE NEWS}

WHAT'S NEW

\section{Motivating children}

The Henry Schein range of motivational products is aimed at making the surgery a more welcoming place, especially for children. Products in the Motivators range include posters, stickers, dental spin tops, glitter bounce balls and toy packs.

Henry Schein also offers a wide selection of novelty products, including teeth key chains, tooth necklaces, tooth pencils, balloons, ties and t-shirts.

The clothing range depicts popular cartoon characters, such as Bugs Bunny visiting the dentist or improving young patients' oral hygiene

Reader response number 50

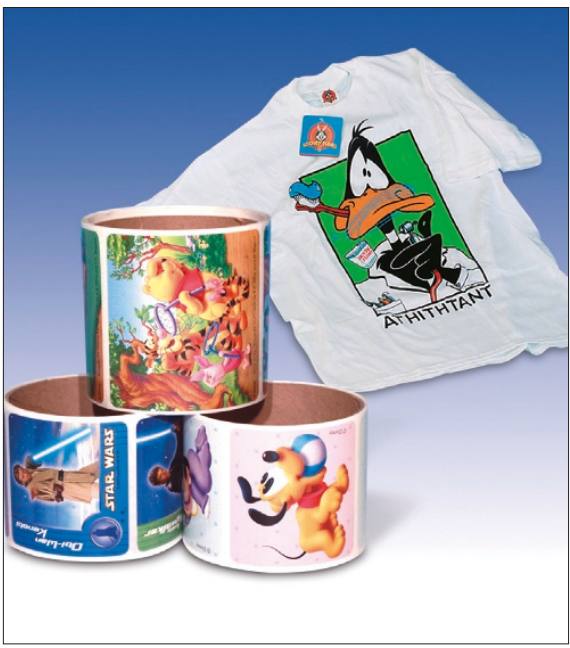

\section{Handy wipes}

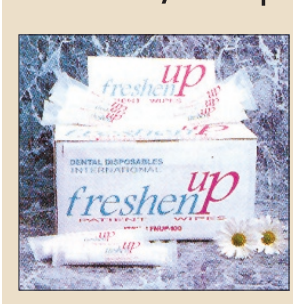

Freshen Up Patient Wipes from Professional Dental Supplies deliver a 'feel good' factor and make patients feel welcome according to the company. Individually wrapped for total hygiene, and with an invigorating lemon scent, these alcohol free wipes can be used directly out of the package at room temperature, or can be microwaved on a low setting for 5-7 seconds and presented warm. Reader response number 51

\title{
Single step restoratives
}

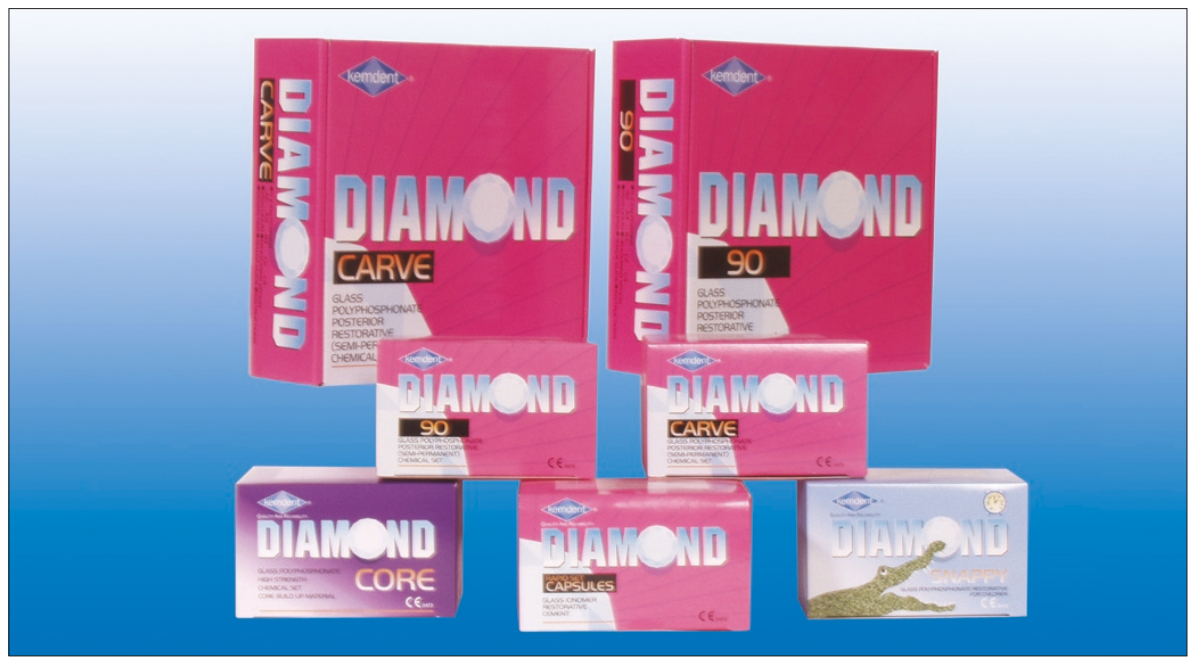

The Diamond range of advanced restorative cements from Kemdent is applied in a single step to save chair time, unlike composites, which require the restoration to be etched, bonded and then built-up. In Kemdent's Winter Sale dentists can buy any two products from the Diamond and receive a $10 \%$ discount. The offer includes Diamond Carve and 90 Packs and Kits, Diamond Snappy, Diamond Rapid Set Capsules and Diamond Core.

Reader response number 52

\section{Healing with BioMend}

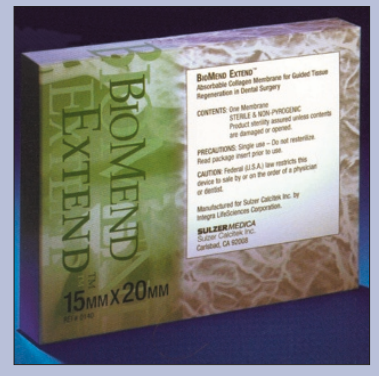

BioMend and BioMend Extend absorbable membranes from Centrepulse Dental are completely resorbable and biocompatible and provide good handling characteristics according to the company.

Available from the Haley Implant Accessory Catalogue, the product functions as a barrier during the critical period for wound healing and remains effective for up to 8 and 18 weeks respectively.

Reader response number 53

\section{Toaster offer}

Alkapharm is offering a free toaster with the purchase of any two disinfectant agents from its range. The range features Alkaspray Plus Economy 5 Litre refills, System-2, 5 Litres of concentrate, Alkacide-30, 5 Litres, ImpressiV, 5 Litres economy refill, Alkazyme, 100 water soluble sachets or Alkazyme 750 grams powder concentrate and Alkazyme-W 500 grams. The products can be purchased in any combination.

Reader response number 54

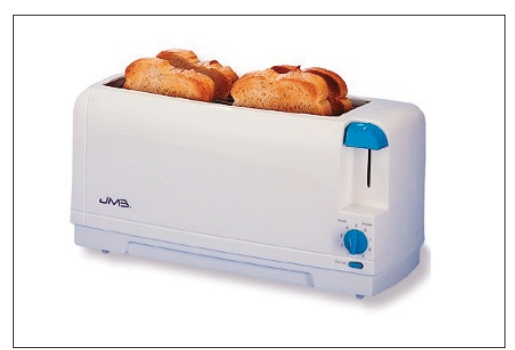

